\title{
Pengaruh suhu penyimpanan terhadap kualitas hasil panen komoditas
} Brassicaceae

Effect of storage temperature on the quality of the harvest product of brassicaceae commodities

\author{
Murtiwulandari Murtiwulandari ${ }^{1)}$, Deshinta Tri Murty Archery ${ }^{1)}$, Megawati \\ Haloho ${ }^{1}$, Rendha Kinasih ${ }^{1)}$, Lois Hintanara Shine Tanggara ${ }^{1)}$, Yetero Hendikus \\ Hulu $^{1)}$, Krisdania Agaperesa ${ }^{1)}$, Novani Wahyu Khristanti ${ }^{1)}$, Yuli Kristiyanto ${ }^{1}$, \\ Surya Seno Pamungkas ${ }^{1)}$, Yoga Aji Handoko ${ }^{1)}$, Gabriella Desnata Yoan Anarki ${ }^{{ }^{*} \text { ) }}$ \\ ${ }^{1}$ Fakultas Pertanian dan Bisnis, Universitas Kristen Satya Wacana, Salatiga, Jawa Tengah \\ *Email: yoan.anarki.ya@gmail.com
}

Info artikel

Dikirim: 21/07/2020; ditinjau: 22/07/2020; disetujui: 20/08/2020

\begin{abstract}
Postharvest handling is recommended to maintain the quality of crop commodities. Brassicaceae is the most popular commodities. The postharvest handling of the Brassicaceae is important to maintain the quality and freshness up to the hand of consumers. This research was conducted to observe the effect of storage temperature on the quality of Brassicaceaeafter seven day of storage. The water content analysis was performed using the gravimetric method, weight loss was analyzed using the weight difference percentage method, respiration rate was analyzed using the $\mathrm{CO}_{2}$ absorption method and continued with titration, Vitamin $C$ content was analyzed using the idiometric titration method, chlorophyll and carotenoids were analyzed using spectroscopy methods using DMSO reagent. Storage of Brassicaceaein the freezer can maintain freshness and good product quality based on low carotenoid content, respiration rate and tissue weight loss value.
\end{abstract}

Keywords: Brassicaceae, postharvest, postharvest handling, temperature, storage

\begin{abstract}
ABSTRAK
Penanganan pascapanen direkomendasikan untuk menjaga kualitas komoditas hasil panen. Brassicaceae adalah salah satu komoditas yang paling banyak diminati masyarakat. Penanganan pascapanen komoditas Brassicaceae menjadi penting untuk menjaga kualitas dan kesegaran hasil panen hingga ke tangan konsumen. Penelitian ini dilakukan untuk mengamati pengaruh suhu penyimpanan terhadap kualitas produk panen Brassicaceae selama kurun waktu tujuh hari masa simpan. Analisis kadar air dilakukan dengan metode gravimetri, susut bobot dianalisis menggunakan metode persentase selisih bobot, laju respirasi dianalisis menggunakan metode penjerapan $\mathrm{CO}_{2}$ dan dilanjutkan dengan titrasi,kandungan vitamin $\mathrm{C}$ dianalisis men8ggunakan metode titrasi idiometri, klorofil dan karotenoid dianalisis menggunakan metode ekstraksi menggunakan DMSO dan diamati menggunakan spektofotometer.Penyimpanan produk panen Brassicaceae pada ruang freezer dapat menjaga kesegaran dan kualitas produk tetap baik berdasarkan rendahnya kandungan karotenoid, penekanan laju respirasi, serta rendahnya nilai susut bobot jaringan.
\end{abstract}

Kata kunci: Brassicaceae, pascapanen, penanganan pascapanen, penyimpanan, suhu 


\section{PENDAHULUAN}

Komoditas hortikultura memiliki potensi yang besar karena memiliki nilai ekonomi tinggi. Salah satu diantaranya ialah komoditas tanaman Brassicaceae, yakni keluarga aneka kubis dan sawi. Jenis komoditas ini sangat digemari masyarakat sehingga berdampak pada tingkat konsumsi dan nilai ekonominya yang tinggi (Rukmana, 1994; Paradis et al., 1995; Haryanto et al., 2007; Wibisono, 2011). Namun demikian, selama proses penyimpanan produk setelah panen mengalami penurunan kualitas yang ditunjukkan dengan perubahan kenampakan fisik serta kimiawi produk panen.

Salah satu perubahan yang sangat mencolok saat penyimpanan adalah susut berat dan perubahan kandungan pigmen (zat warna) dalam jaringan. Dengan turunnya kandungan klorofil, maka pigmen-pigmen lainnya dapat bertambah ataupun berkurang pada suhu simpan, kemasan, dan varietasnya. Lama penyimpanan juga memiliki pengaruh yang cukup besar terhadap kandungan vitamin $\mathrm{C}$ produk hortikultura selama penyimpanan. Hal ini disebabkan selama penyimpanan respirasi terus terjadi kenaikan dimana akan terbentuk gula-gula sederhana yang bertindak sebagai prekursor dalam pembentukan vitamin C. Peningkatan kandungan vitamin $\mathrm{C}$ biasanya akan terjadi seiring lamanya waktu penyimpanan akan tetapi apabila substrat pembentukan vitamin $\mathrm{C}$ tidak lagi tersedia maka kandungan vitamin $\mathrm{C}$ akan mengalami penurunan (Hasanah, 2009).

Penanganan pascapanen komoditas Brassicaceae menjadi penting untuk menjaga kualitas dan kesegaran hasil panen hingga ke tangan konsumen.Penanganan pasca panen buah dan sayuran di Indonesia belum mendapat perhatian yang cukup. Hal ini terlihat dari kerusakan pasca panen sebesar 25\%-28\%. Mengemas produk segar dengan plastik dapat menyebabkan adanya perubahan atau modifikasi konsentrasi $\mathrm{CO}_{2}$ dan $\mathrm{O}_{2}$ sekitar produk di dalam kemasan.Kemasan plastik memiliki permeabilitas udara yang sangat rendah sehingga mengakibatkan konsentrasi $\mathrm{CO}_{2}$ akan meningkat dan $\mathrm{O}_{2}$ menurun. Penggunaan plastik sebagai bahan kemasan buah-buahan dapat memperpanjang masa simpan produk hortikultura segar yang mana dapat memperlambat perubahan fisiologis yang berhubungan dengan pemasakan dan pelayuan dari produk hortikultura (Wiryanta, 2009).

Salah satu cara yang juga efektif dalam melakukan penangan pasca panen ialah dengan menurunkan laju respirasi dan metabolisme dari produk panen. Penekanan lajurespirasi dan metabolisme dapat dilakukan dengan menurunkan suhu ruang penyimpanan produk panen(Rachmawati, 2010).Suhu rendah dapat memperpanjang umur simpan sayuran dan dapat mengurangi aktifitas enzim klorofilase yang merusak klorofil (Rohmat, 2014). Maka dari itu, disusunlah penelitian ini untuk mengetahui pengaruh suhu penyimpanan terhadap kualitas produk Brassicaceae selama masa simpan setelah panen.

\section{METODE}

\section{Bahan}

Sampel yang digunakan adalah hasil panen komoditas Brassicaceae yaitu kubis merah (Brassica oleracea var. Capitata forma rubra), selada krop (Lactuca sativa var. Capitata), brokoli (Brassica oleracea var. Italica), dan bunga kol (Brassica oleracea var. Botrytis). Larutan dan reagen yang digunakan dalam penelitian ini adalah akuades, $\mathrm{KOH}, \mathrm{HCl}, \mathrm{I}_{2}$, DMSO, dan larutan indikator PP.

\section{Alat}

Alat yang digunakan antara lain plastik pengemas (plastic wrap), lemari berpendingin dengan suhu $26^{\circ} \mathrm{C}$ (suhu ruang), suhu $5^{\circ} \mathrm{C}$ (suhu lemari berpendingin / kulkas), dan suhu $-4^{\circ} \mathrm{C}$ (suhu lemari beku / freezer), oven dengan suhu $105^{\circ} \mathrm{C}$ dan botol timbang, timbangan digital, erlenmeyer, selang karet, aerator, statif dan buret, serta seperangkat alat tulis dan dokumentasi. 


\section{Metode}

Masing-masing sampel dikemas menggunakan plastic-wrap dan disimpan selama tujuh hari. Perlakuan penyimpanan pada tiga suhu berbeda yaitu suhu $26^{\circ} \mathrm{C}$ (suhu ruang), suhu $5^{\circ} \mathrm{C}$ (suhu lemari berpendingin / kulkas), dan suhu $-4^{\circ} \mathrm{C}$ (suhu lemari beku / freezer).

Analisis kadar air jaringan dilakukan dengan metode gravimetri pada suhu pengeringan $105^{\circ} \mathrm{C}$ dan lama pengeringan 2 jam. Kadar air dinyatakan dalam satuan persen (\%) dan dihitung dengan rumus

$$
\text { Kadar Air }=\frac{(\text { bobot sebelum dikeringkan })-(\text { bobot setelah dikeringkan })}{(\text { bobot sebelum dikeringkan })} \times 100 \times \%
$$

Susut bobot jaringan dinyatakan dalam satuan persen (\%) dihitung dengan rumus

$$
\text { Susut Bobot }=\frac{(\text { bobot awal })-(\text { bobot hari pengamatan })}{(\text { bobot awal })} \times 100 \times \%
$$

Laju respirasi jaringan dianalisis dengan metode penjerapan $\mathrm{CO}_{2}$ dan dilanjutkan dengan titrasi asam-basa. Laju respirasi dinyatakan dalam satuan $\mathrm{mg} \mathrm{CO}_{2} \mathrm{~g}^{-1}$ menit ${ }^{-1}$ dihitung dengan rumus

$$
\text { Laju Respirasi }=\frac{(\text { titrasi blanko }- \text { titrasi sampel }) \times \text { molaritas titran }}{(\text { bobot sampel } / \text { waktu penjerapan analisis })}
$$

Keterangan:

Molaritas titran $\quad: 0,1$

Waktu penjerapan : 20 menit

Kandungan klorofil dan karotenoid pada panjang gelombang 480nm, 649nm, dan dianalisis dengan metode ekstraksi 665nm. Kandungan klorofil dan karotenoid menggunakan dimetil sulfoksida (DMSO) dinyatakan dalam satuan $\mu \mathrm{g} \mathrm{g}^{-1}$ sampel dan dan diamati menggunakan spektrofotometer dihitung dengan rumus:

Klorofil $A=\{(12,19 x$ absorbansi $\lambda 665 \mathrm{~nm})-(3,45 x$ absorbansi $\lambda 649 \mathrm{~nm})\} \times 0,125$

Klorofil $B=\{(21,99 \times$ absorbansi $\lambda 649 \mathrm{~nm})-(5,32 \times$ absorbansi $\lambda 665 \mathrm{~nm})\} \times 0,125$

Total Klorofil $=\{(18,54 x$ absorbansi $\lambda 649 \mathrm{~nm})+(6,87 \times$ absorbansi $\lambda 665 \mathrm{~nm})\} \times 0,125$

Karotenoid $=\frac{(1000 \times \text { absorbansi } \lambda 480 \mathrm{~nm})-(2,14 \times \text { klorofil } A)-(70,16 \times \text { klorofil } B)}{220} \times 0,125$

Kandungan vitamin $\mathrm{C}$ pada jaringan sampel dianalisis dengan metode titrasi idiometri. Vitamin $\mathrm{C}$ dinyatakan dalam satuan $\mathrm{mg} 10 \mathrm{~g}^{-1}$ sampel dan dihitung menggunakan rumus:

Vitamin $C=$ volume titrasi $x 8,8$

\section{HASIL DAN PEMBAHASAN}

\section{Kadar air}

Herawati (2008) menuliskan bahwa faktor yang sangat berpengaruh terhadap penurunan mutu produk pangan adalah perubahan kadar air dalam produk. Perubahan kadar air dipengaruhi oleh suhu dan kelembaban ruangan selama penyimpanan. Data hasil penelitian dapat dilihat bahwa tanaman selada krop yang diletakkan pada suhu ruang memiliki kadar air tertinggi dibandingkan dengan tanaman jenis Brasicca lainnya dengan nilai kadar air 96\%. Singh dan Sagar (2010) menyebutkan sayuran yang dikemas mengalami peningkatan kadar air selama penyimpanan dan peningkatan pada suhu kamar relatif lebih tinggi dibandingkan dengan suhu rendah. Hal ini terjadi akibat adanya jumlah air metabolit sebagai hasil samping proses respirasi lebih banyak dibandingkan dengan air yang menguap melalui proses transpirasi, sehingga terjadi akumulasi air di antara sel. 
Tabel 1. Kadar air hasil panen komoditas Brassicaceae setelah panen dan setelah masa simpan

\begin{tabular}{lcccc}
\hline \multirow{2}{*}{ Komoditas } & \multicolumn{4}{c}{ Kadar air (\%) } \\
\cline { 2 - 5 } & Awal & Suhu $\mathbf{2 5}^{\mathbf{0}} \mathbf{C}($ Ruang) & Suhu 5 $\mathbf{C}($ Kulkas) & Suhu -4 $\mathbf{C}^{\mathbf{0}}($ Freezer $)$ \\
\hline Kubis merah & 87.00 & 87.40 & 82.40 & 87.20 \\
Selada krop & 95.80 & 96.00 & 96.00 & 73.80 \\
Brokoli & 86.60 & 86.60 & 83.40 & 90.00 \\
Bunga kol & 91.20 & 79.20 & 77.20 & 87.00 \\
\hline Rerata & $\mathbf{9 0 . 1 5}$ & $\mathbf{8 7 . 3}$ & $\mathbf{8 4 . 7 5}$ & $\mathbf{8 4 . 5}$ \\
\hline
\end{tabular}

\section{Susut bobot}

Hasil pengamatan menunjukkan pada suhu penyimpanan ruang, susut bobot pada komoditas Brassicaceae lebih tinggi dibandingkan nilai rata-rata perlakuan suhu lainnya, yaitu sebesar $8,18 \%$. Besarnya nilai susut bobot dapat disebabkan dari tingginya suhu penyimpanan yang meningkatkan laju transpirasi dan respirasi (Roys, 1995).Komoditas Brassica yang disimpan pada freezer menunjukkan susut bobot yang relatif lebih rendah dibandingkan hasil ratarata perlakuan suhu lainnya, dengan rata-rata nilai sebesar 2,44\%. Hal ini sesuai dengan pendapat Pantastico et al. (1989), bahwa pada suhu rendah laju respirasi produk pasca panen terhambat sehingga susut beratnya pun juga akan terhambat. Musaddad (2013) menuliskan bahwa penyimpanan pada suhu rendah (pendinginan) merupakan cara untuk menghambat laju penurunan mutu sayuran melalui 2 prinsip dasar, yaitu memperlambat kecepatan reaksi metabolisme sehingga dapat menghambat laju penurunan fisiologis dan menghambat pertumbuhan mikroorganisme penyebab kebusukan dan kerusakan.

Tabel 2. Persentase susut bobot hasil panen komoditas Brassicaceae setelah masa simpan

\begin{tabular}{|c|c|c|c|}
\hline \multirow{2}{*}{ Komoditas } & \multicolumn{3}{|c|}{ Susut bobot (\%) } \\
\hline & Suhu $25^{\circ} \mathrm{C}$ (Ruang) & Suhu $5^{\circ} \mathrm{C}$ (Kulkas) & Suhu $-4^{\circ} \mathrm{C}($ Freezer $)$ \\
\hline Kubis merah & 12.06 & 7.25 & 8.67 \\
\hline Selada krop & 5.34 & 0.65 & 0.39 \\
\hline Brokoli & 9.71 & 1.21 & 0.31 \\
\hline Bunga kol & 5.64 & 1.52 & 0.41 \\
\hline Rerata & 8.18 & 3.04 & 2.44 \\
\hline
\end{tabular}

Penurunan bobot yang kecil sangat diharapkan selama masa simpan. Penurunan susut bobot ini erat hubungannya dengan kandungan air dan perubahan cadangan makanan pada hasil panen. Jaringan tanaman tetap hidup setelah pemanenan dan tetap mengalami proses respirasi serta kehilangan air (Burdon, 1997 dalam Mudyantini dkk., 2015). Kehilangan air dari komoditas, selain dipengaruhi oleh suhu penyimpanan, dipengaruhi juga oleh kelembaban nisbi lingkungan sekitarnya. Susut bobot yang berlebihan dari komoditas menyebabkan pelayuan dan pengeriputan sehingga kesegarannya pun berkurang (Ryall dan Lipton, 1983). Susut bobot yang semakin besar seiring dengan semakin lamanya penyimpanan,terjadi bukan hanya karena kehilangan air selama proses transpirasi, tetapi dapat diakibatkan oleh kehilangan karbon selama proses respirasi masih berlangsung (Soesarsono, 1981). Pengaruh lebih nyata akibat kehilangan air adalah perubahan pada rupa (kenampakan), kelayuan atau pengkerutan. Kehilangan berat pada hasil panen diakibatkan pula oleh proses respirasi dan transpirasi. Sebagian besar sayuran yang memiliki nilai susut bobot sekitar 3-6\% dapat menyebabkan hilangnya kualitas dan pada sebagian kecil sayuran susut bobot sebesar $10 \%$ menyebabkan sayuran tidak berharga lagi (Woodroof, 1982).

\section{Laju respirasi}

Laju kerusakan pada produk pertanian terjadi berbanding lurus dengan kecepatan respirasi yang dimiliki masing - masing komoditas yakni semakin cepat laju respirasinya semakin cepat pula terjadi kerusakan pada komoditas tersebut. Maka dari itu, perludiperhatikan beberapa hal agar produk yang dikemas tidak mengalami 
kerusakan, diantaranya: kemasan harus kedap gas, dapat memberikan efek atmosfir termodifikasi, dan tidak mencemari/bereaksi dengan produk yang dikemas (Soesarsono, 2003).

Tabel 3. Laju respirasi hasil panen komoditas Brassicaceae setelah panen dan setelah masa simpan

\begin{tabular}{lcccc}
\hline \multirow{2}{*}{ Komoditas } & \multicolumn{4}{c}{ Laju respirasi $\left(\mathbf{m l ~ C O}_{\mathbf{2}} \mathbf{g}^{\mathbf{1}} \mathbf{m e n i t}^{\mathbf{- 1}}\right)$} \\
\cline { 2 - 5 } & Awal & Suhu $\mathbf{2 5}^{\mathbf{0}} \mathbf{C}($ Ruang) & Suhu $\mathbf{5}^{\mathbf{0}} \mathbf{C}($ Kulkas$)$ & Suhu $\mathbf{- 4}^{\mathbf{0}} \mathbf{C}($ Freezer $)$ \\
\hline Kubis merah & 0.009 & 0.025 & 0.025 & 0.001 \\
Selada crop & -0.007 & 0.031 & 0.023 & 0.010 \\
Brokoli & 0.032 & 0.028 & 0.001 & 0.019 \\
Bunga kol & 0.101 & 0.023 & 0.016 & 0.010 \\
\hline Rerata & $\mathbf{0 . 0 3 4}$ & $\mathbf{0 . 0 2 7}$ & $\mathbf{0 . 0 1 6}$ & $\mathbf{0 . 0 1 0}$ \\
\hline
\end{tabular}

Semua komoditas Brassicaceae yang digunakan sebagai sampel menunjukkan bahwa semakin rendah suhu ruang penyimpanan, maka nilai laju respirasinya juga semakin kecil. Tercatat bahwa laju respirasi pada sampel setelah perlakuan penyimpanan, ruang freezermemberikan nilai laju respirasi terendah yaitu sebesar $0.010 \mathrm{ml}$ $\mathrm{CO}_{2} \mathrm{~g}^{-1}$ menit ${ }^{-1}$, sedangkan penyimpanan pada suhu ruang memberikan nilai laju respirasi terbesar yaitu $0.027 \mathrm{ml} \mathrm{CO}_{2} \mathrm{~g}^{-1}$ menit $^{-1}$.

Intensitas respirasi dianggap sebagai ukuran laju jalannya metabolisme, dan oleh karena itu sering dianggap sebagai petunjuk mengenai potensi daya simpan sayur. Laju respirasi yang tinggi pada produk sayur menyebabkan umur simpannya menjadi pendek. Hal ini juga menjadi petunjuk laju kemunduran mutu dan nilai sebagai bahan makanan. Suhu adalah faktor penting yang mempengaruhi laju respirasi dilihat dari segi penyimpanan. Peningkatan suhu antara $0^{\circ} \mathrm{C}$ $35^{\circ} \mathrm{C}$ akan meningkatkan laju respirasi buah- buahan dan sayuran, yang memberi petunjuk bahwa baik proses biologi maupun proses kimiawi dipengaruhi oleh suhu (Dwidjoseputro, 1990).

\section{Vitamin C}

Safaryani (2007)menuliskan bahwa stabilitas vitamin $\mathrm{C}$ biasanya meningkat seiring dengan penurunan suhu penyimpanan, akan tetapi selama pembekuan terjadi kerusakan jaringan yang cukup besar pada bahan yang disimpan, sehingga menyebabkan stabilitas vitamin $\mathrm{C}$ menurun. Data di atas menunjukkan bahwa penurunan suhu penyimpanan hingga $5^{\circ} \mathrm{C}$ (suhu kulkas) memberikan nilai rerata kandungan vitamin $\mathrm{C}$ yang tidak jauh berbeda dengan perlakuan penyimpanan pada suhu ruang, dengan selisih rerata sebesar $0.32 \mathrm{mg}$. Namun, penyimpanan pada freezer menyebabkan nilai kandungan vitamin $\mathrm{C}$ yang lebih rendah, yaitu $12.32 \mathrm{mg}$ per $10 \mathrm{~g}$ sampel.

Tabel 4. Kandungan vitamin C (asam askorbat) hasil panen komoditas Brassicaceae setelah panen dan setelah masa simpan

\begin{tabular}{|c|c|c|c|c|}
\hline \multirow{2}{*}{ Komoditas } & \multicolumn{4}{|c|}{ Vitamin C (mg 10g ${ }^{-1}$ sampel) } \\
\hline & Awal & Suhu $25^{\circ} \mathrm{C}$ (Ruang) & Suhu $5^{\circ} \mathrm{C}$ (Kulkas) & Suhu $-4^{\circ} \mathrm{C}$ (Freezer) \\
\hline Kubis Merah & 14.96 & 19.36 & 14.96 & 16.72 \\
\hline Selada crop & 6.16 & 6.16 & 13.20 & 8.80 \\
\hline Brokoli & 9.68 & 25.22 & 22.20 & 14.08 \\
\hline Bunga kol & 7.04 & 12.32 & 11.44 & 9.68 \\
\hline Rerata & 9.46 & 15.77 & 15.45 & 12.32 \\
\hline
\end{tabular}

Kandungan vitamin $\mathrm{C}$ pada komoditas setelah masa simpan menunjukkan nilai yang lebih besar dibanding pada analisis awal. Hal ini mungkin terjadi akibat proses pelayuan yang terjadi selama masa simpan. Meningkatnya kandungan vitamin $\mathrm{C}$ selama fase pelayuan terjadi akibat adanya pembentukan vitamin $\mathrm{C}$ yang berasal dari substrat glukosa 6-PO4. Peningkatan kandungan vitamin $\mathrm{C}$ biasanya akan terjadi seiring lamanya waktu penyimpanan akan tetapi apabila substrat pembentukan vitamin $\mathrm{C}$ tidak lagi tersedia maka kandungan 
vitamin C akan mengalami penurunan (Safaryani, 2007).

\section{Total klorofil}

Klorofil dikatakan sudah rusak jika kadar klorofil turun hingga 50\%.Data pada Tabel 5 menunjukkan bahwa semakin rendah suhu penyimpanan, maka kandungan klorofil yang diamati setelah masa simpan semakin besar nilainya. Penyimpanan pada ruang freezer mampu mempertahankan kandungan klorofil sebesar $68 \%$ dari nilai awal sebelum perlakuan penyimpanan. Penyimpanan pada suhu ruang dan suhu kulkas menunjukkan degradasi klorofil yang relatif besar dengan kandungan klorofil yang mampu dipertahankan berturut-turut sebesar $11 \%$ dan 16\% saja.Rendahnya kandungan pigmen klorofil pada penyimpanan suhu ruang diduga karena suhu tersebut sudah dapat mengurangi aktivitas enzim klorofilase yang merusak klorofil. Penyimpanan pada suhu rendah dapat mengurangi aktivitas enzim klorofilase sebanyak $50 \%$ dibandingkan dengan penyimpanan pada suhu ruang. Suhu rendah dapat memperpanjang umur simpan klorofil pada sayuran (Rohmat, 2014).

Tabel 5. Kandungan total klorofil hasil panen komoditas Brassicaceae setelah panen dan setelah masa simpan

\begin{tabular}{|c|c|c|c|c|}
\hline \multirow{2}{*}{ Komoditas } & \multicolumn{4}{|c|}{$\begin{array}{c}\text { Total Klorofil }\left(\mu \mathrm{g} \mathrm{g}^{-1}\right) \\
\end{array}$} \\
\hline & Awal & Suhu $25^{\circ} \mathrm{C}$ (Ruang) & Suhu $5^{\circ} \mathrm{C}$ (Kulkas) & Suhu $-4^{\circ} \mathrm{C}$ (Freezer $)$ \\
\hline Kubis merah & 0.55 & 0.18 & 0.05 & 0.21 \\
\hline Selada crop & 0.64 & 0.14 & 0.19 & 0.44 \\
\hline Brokoli & 2.32 & 0.05 & 0.43 & 2.06 \\
\hline Bunga kol & 0.83 & 0.10 & 0.04 & 0.23 \\
\hline Rerata & 1.085 & 0.118 & 0.178 & 0.735 \\
\hline
\end{tabular}

Warna menjadi indikator kesegaran untuk komoditas sayuran, termasuk produk panen Brassicaceae. Suhu penyimpanan sangat mempengaruhi tingkat kecerahan sehingga warna tetap bisa terjaga. Proses respirasi yang lebih cepat dapat meningkatkan degradasi pigmen,sedangkan penurunan laju respirasi menyebabkan pematangan dan perubahan warna terhambat. Konsentrasi $\mathrm{O}_{2}$ yang rendah dapat berpengaruh terhadap laju respirasi dan oksidasi substrat menurun, pematangan tertunda dan sebagai akibatnya umur komoditi menjadi lebih panjang, perombakan klorofil tertunda dan produksi $\mathrm{C}_{2} \mathrm{H}_{4}$ rendah. Hilangnya warna hijau merupakan peralihan dari fungsi kloroplas ke kromoplas yang mengandung pigmen karotenoid.Seiring dengan lamanya masa simpan dan metabolisme yang terus berjalan, maka terjadi degradasi klorofil sehingga terjadi perubahan warna dari hijau menjadi kuning sampai merah (Johansyah, 2014).

\section{Total karotenoid}

Susanto (1994) menyatakan bahwa kandungan karotenoid akan meningkat pada permulaan senescene. Kandungan karotenoid akan meningkat seiring dengan degradasi klorofil pada jaringan sayuran. Total karotenoid setelah dilakukan pengujian dan analisis memiliki nilai rata-rata pada perlakuan awal sebesar $0.03 \quad \mu \mathrm{g} \quad \mathrm{g}^{-1}$. Penyimpanan pada freezer memberikan nilai kandungan karotenoid yang terendah dibandingkan dengan perlakuan penyimpanan yang lain, yang tercatat sebesar $-0.03 \mu \mathrm{g} \mathrm{g}^{-1}$. Penyimpanan pada suhu yang lebih tinggi memberikan hasil kandungan karotenoid yang lebih besar pula, dimana suhu ruang dan suhu kulkas berturut-turut memberikan nilai sebesar $0.05 \mu \mathrm{g} \mathrm{g}^{-1} \mathrm{dan}$ $0.0875 \mu \mathrm{g} \mathrm{g}^{-1}$. 
Tabel 6. Kandungan total karotenoid hasil panen komoditas Brassicaceae setelah panen dan setelah masa simpan

\begin{tabular}{|c|c|c|c|c|}
\hline \multirow{2}{*}{ Komoditas } & \multicolumn{4}{|c|}{ Total Karotenoid $\left(\mu \mathrm{g} \mathrm{g}^{-1}\right)$} \\
\hline & Awal & Suhu $25^{\circ} \mathrm{C}$ (Ruang) & Suhu $5^{\circ} \mathrm{C}$ (Kulkas) & Suhu $-4^{\circ} \mathrm{C}($ Freezer $)$ \\
\hline Kubis merah & 0.08 & 0.06 & 0.05 & 0.03 \\
\hline Selada crop & 0.08 & 0.02 & 0.10 & 0.16 \\
\hline Brokoli & -0.13 & 0.10 & 0.18 & -0.31 \\
\hline Bunga kol & 0.09 & 0.02 & 0.02 & 0.00 \\
\hline Rerata & 0.030 & 0.050 & 0.0875 & -0.030 \\
\hline
\end{tabular}

\section{Korelasi perlakuan dan antar parameter}

Perlakuan variasi suhu penyimpanan memberikan pengaruh terhadap kualitas komoditas sayuran yang disimpan. Tabel 7 menunjukkan bahwa suhu penyimpanan memberikan pengaruh yang paling besar terhadap kandungan total karotenoid dengan nilai korelasi positif. Artinya, semakin rendah suhu penyimpanan maka kandungan karotenoid juga semakin rendah, begitu pula sebaliknya. Hal ini menunjukkan bahwa suhu penyimpanan yang semakin rendah dapat membantu menjaga kualitas dan kesegaran produk panen, khususnya Brassicaceae, dimana kandungan karotenoid yang menjadi penanda adanya degradasi klorofil sebagai bentuk kemunduran kualitas sayur.

Tabel 7. Nilai korelasi perlakuan suhu penyimpanan terhadap parameter kualitas hasil panen komoditas Brassicaceae selama masa simpan setelah panen

\begin{tabular}{cc}
\hline Parameter pengamatan & Nilai korelasi terhadap suhu penyimpanan \\
\hline Kadar air & 0.04 \\
Susut bobot & 0.69 \\
Laju respirasi & 0.87 \\
Vitamin C & 0.60 \\
Total klorofil & -0.18 \\
Total karotenoid & 0.98 \\
\hline
\end{tabular}

Perlakuan suhu penyimpanan juga memberikan nilai korelasi yang cukup tinggi pada amatanlaju respirasi. Nilai ini menunjukkan bahwa suhu penyimpanan memberikan pengaruh yang signifikan terhadap laju respirasi dari komoditas yang diamati. Korelasi yang positif menunjukkan bahwa semakin rendah suhu penyimpanan akan diikuti pula dengan turunnya laju respirasi dari komoditas. Artinya bahwa perlakuan penurunan suhu penyimpanan efektif untuk menurunkan proses metabolisme jaringan dari komoditas Brassicaceae, terutama laju respirasi, yang kemudian akan berpengaruh pada kualitas dan kesegaran produk.

Tabel 8. Nilai korelasi antar parameter dalam pengaruh perlakuan suhu penyimpanan terhadap kualitas hasil panen komoditas Brassicaceae selama masa simpan setelah panen

\begin{tabular}{lrrrrr}
\hline \multicolumn{1}{c}{$\begin{array}{c}\text { Parameter } \\
\text { pengamatan }\end{array}$} & $\begin{array}{c}\text { Kadar } \\
\text { air }\end{array}$ & $\begin{array}{c}\text { Susut } \\
\text { bobot }\end{array}$ & $\begin{array}{c}\text { Laju } \\
\text { respirasi }\end{array}$ & $\begin{array}{c}\text { Vitamin } \\
\text { c }\end{array}$ & $\begin{array}{c}\text { Total } \\
\text { klorofil }\end{array}$ \\
\hline Kadar air & 1 & & & & \\
Susut bobot & 0.75 & 1 & & & \\
Laju respirasi & -0.47 & 0.23 & 1 & & \\
Vitamin C & 0.82 & 0.99 & 0.11 & & \\
Total klorofil & 0.98 & 0.60 & -0.64 & 0.69 & 1 \\
Total karotenoid & -0.15 & 0.54 & 0.94 & 0.43 & -0.36 \\
\hline
\end{tabular}

Tabel 8 menunjukkan bahwa susut bobot berhubungan sangat erat dengan kandungan vitamin $\mathrm{C}$ pada jaringan. Semakin besar nilai susut bobot yang dihasilkan, maka semakin besar pula kandungan vitamin $\mathrm{C}$ yang tercatat. Kadar air memiliki hubungan yang cukup erat dengan kandungan klorofil, vitamin $\mathrm{C}$ dan nilai susut bobot. Tingginya nilai kadar air dalam jaringan akan diikuti pula dengan tingginya kandungan klorofil yang teramati. Selain itu, kandungan vitamin $\mathrm{C}$ dan nilai susut bobot juga akan meningkat. 


\section{KESIMPULAN}

Perlakuan variasi suhu penyimpanan berpengaruh terhadap kualitas produk Brassicaceaeyang disimpan. Suhu yang semakin rendah memberikan dampak yang lebih baik, diamati dari nilai total karotenoid, laju respirasi, susut bobot, dan kandungan vitamin C. Penyimpanan produk panen Brassicaceae pada ruang freezer dapat menjaga kesegaran dan kualitas produk tetap baik berdasarkan rendahnya kandungan karotenoid, penekanan laju respirasi, serta rendahnya nilai susut bobot jaringan.

\section{UCAPAN TERIMA KASIH}

Terima kasih mendalam untuk Bapak Kurniawan Andrianto, S.P. selaku laboran Laboratorium Benih dan Teknik Pengolahan Hasil Pertanian, Fakultas Pertanian dan Bisnis UKSW, Ibu Wamilia Yulianingsih, S. Si. dan Saudari Vania Putri Santosa sebagai asisten dosen matakuliah Penanganan Pascapanen Fakultas Pertanian dan Bisnis UKSW atas pendampingan dan bantuan baik secara materi maupun moral dalam penyusunan penelitian dan penulisan laporan ini.

\section{DAFTAR PUSTAKA}

Dwidjoseputro. (1990). Dasar-dasar mikrobiologi. Jakarta: Djambatan.

Firmansyah, Y., Raswen, E., \& Rahmayuni. (2016). Pemanfaatan kitosan untuk memperpanjang umur simpan buah pepaya varietas california. Jurnal Sagu, 15(2), 11-20.

Hasanah, U. (2009). Pemanfaatan gel lidah buaya sebagai edible coating untuk memperpanjang umur simpan paprika (Capsicum annum varietas sunny) [Skripsi, Fakultas Teknologi Pertanian Institut Pertanian Bogor]. http://repository.ipb.ac.id/handle/12345 6789/12118

Haryanto, E., Suhartini , T., Estu, R., \& Sunarjono, H. H. (2007). Sawi \& selada. Jakarta: Penebar Swadaya.
Herawati, H. (2008). Penentuan umur simpan pada produk pangan. Prosiding Jurnal Litbang Pertanian, 27(4), 124-130.

Johansyah, A., Prihastanti, E., \& Kusdiyantin, E. (2014). Pengaruh plastik pengemas low density polyethylene (LDPE), high density polyethylene (HDPE) dan polipropilen (PP) terhadap penundaan kematangan buah tomat (Lycopersicon esculentumMill).Buletin Anatomi dan Fisiologi, 23(1), 46-57.

Mudyantini, W., Anggarwulan, E., \& Rahayu, P. (2015). Penghambatan pemasakan buah srikaya (Annona squamosaL.) dengan suhu rendah dan pelapisan kitosan. Agric, 27(1), 23-29.

Musaddad, D. (2013). Laju perubahan mutu kubis bunga diolah minimal pada berbagai pengemasan dan suhu penyimpanan. Jurnal Hortikultura, 23(2), 184-194.

Pantastico, E. B., Chachin, K., Ogata, K., \& Phan, C. (1989). Fisiologi pasca panen, penanganan dan pemanfaatan buah-buahan dan sayur-sayuran tropika dan subtropika. Yogyakarta: Gadjah Mada University Press.

Paradis, C., Castaigne, F., Desrosiers, T., \& Willemot, C. (1995). Evaluation of vitamin c, $\beta$-carotene and chlorophyll content in broccoli heads and florets during storage in air. Sciences des Aliments, 15(2), 113-123.

Rachmawati, M. (2010).Pelapisan chitosan pada buah salak pondoh (Salacca edulis Reinw,) sebagai upaya memperpanjang umur simpan dankajian sifat fisiknya selama penyimpanan. Jurnal Teknologi Pertanian, 6(2), 45-49.

Rohmat, N., Ibrahim, R., \& Riyadi, P. H. (2014). Pengaruh perbedaan suhu dan lama penyimpanan rumput laut Sargassum polycistum terhadap stabilitas ekstrak kasar pigmen klorofil. Jurnal Pengolahan dan Bioteknologi Hasil Perikanan, 3(1), 118-126.

Roys, R., Annantheswaran, R. C. \& Beelman, R. B. (1995). Fresh 
mushroom quality asaffected/ modified atmosphere packaging. Journal of Food Science, 60(2), 334-340.

Rukmana. (1994). Bertanam selada dan andewi. Yogyakarta: Kanisius.

Ryall, A.L \& Lipton, W.A. (1983). Handling, transportation and storage of fruits and vegetables. Connecticut: AVI Publishing Company Inc., Westport.

Safaryani, N. (2007). Pengaruh suhu dan lama penyimpanan terhadap penurunan kadar vitamin C brokoli (Brassica oleracea L).Buletin Anatomi dan Fisiologi, 15(2), 39-45.

Singh, U. \& Sagar, V. R. (2010). Quality characteristic of dehydrated leafy vegetables influenced by packing material and storage temperature. Journal of Science and Industrial Research, 69(1), 785-789.
Soesarsono. (2003). Melakukan pengemasan secara manual. Jakarta: Erlangga.

Susanto, T. (1994). Fisiologi dan teknologi pasca panen. Yogyakarta: Akademika.

Woodroof, J. G. (1982). Peanuts: production, processing, products $\left(3^{\text {rd }}\right.$ ed).Connecticut: AVI Publishing Company, Inc., Westport.

Wibisono, H. (2011). Analisis efisiensi usahatani kubis (studi empiris di Desa Banyuroto Kecamatan Sawangan Kabupaten Magelang [Skripsi, Fakultas Ekonomi Universitas Diponegoro Semarang]. http://eprints.undip.ac.id/28080/

Wiryanta, B. T. W. (2009).Bertanam tomat. Jakarta: AgroMedia Pustaka. 